\title{
DIAGNOSIS OF AVIAN TUBERCULOSIS-MYCOBACTERIOSIS BY RAPID AGGLUTINATION
}

\author{
M. PAVLAS,* Alena MICHALSKÁ, M. HUŇADY \\ *Veterinary Research Institute, 62132 Brno \\ Bioveta, 68323 Ivanovice na Hané
}

Received September 7, 1992

\begin{abstract}
Pavlas M., Alena Michalská, M. Huňady: Diagnosis of Avian Tuberculosis-Mycobacteriosis by Rapid Agglutination. Acta vet. Brno, 62, 1993: 63-69.

In contrast to the intradermal tuberculin test (ITT) the sensitivity and specificity of rapid agglutination (RA) using the $M$. avium serovar 2, 3 antigen increased at advanced stages of the infection. Only $47.7 \%$ of pullets, infected orally with $1 \mathrm{mg}$ of: a culture of a virulent strain of $M$. avium serovar 2 per $1 \mathrm{~kg}$ body mass, reacted to avian tuberculin, while RA yielded, at the sama stage of infection, $61.6 \%$ and $90.9 \%$ of positive results when whole blood and blood serum were examined, respectively. Birds reacting to avian tuberculin were found in some avian tuberculosis-free farms. Contamination of sawdust, used as the litter, with $M$. intracellulare serovar 8 was a frequent cause of such reactions. RA with $M$. avium antigen (MAA) was also used successfully for the differentiation of paraallergic from specific reactions to avian tuberculin. Parallel examination by ITT and RA is recommended as a component of programmes of avian tuberculosis elimination. Moreover RA can replace ITT in screening of tuberculosis in poultry flocks and bird colonies. Examination of blood sera, yielding more accurate results, in recommended in birds kept in zoological gardens and in rearing colonies of predatory birds. RA with MAA is more specific than ITT. Considering the existence of pathogenic strains of $M$. avium which cannot be classed with any of the reference serovars 1,2 and 3, continuous attention should be paid to the selection of avian mycobacterial strains for the production of the antigen.

Poultry, free-living birds, captive birds, diagnosis, avian tuberculosis, mycobacteriosis, rapid agglutination
\end{abstract}

After the eradication of bovine tuberculosis from Czechoslovakia in 1968, Mycobacterium avium has become the most important pathogenic mycobacterium infecting not only farms animals, but also free-living birds and mammals. It is well established that, as far as domesticated birds. are concerned, avian tuberculosis affects more frequently chickens than pigeons or water fowl.

Occurrence of tuberculosis in gallinaceous birds is usually associated with extensive poultry husbandry. The relationship between poultry husbandry methods and infection rate was reported by many authors. The current replacement of extensive husbandry by the all-in-all-out systems not only in large poultry operations, but also in smaller farms, is accompanied by a retreat of avian tuberculosis.

Despite considerable variations of reliability, the intradermal tuberculin test (ITT) remains. the most frequently used method of diagnosis of avian tuberculosis-mycobacteriosis. The reliability of detection of birds infected with $M$. avium decreases especially in flocks with high infection rates, and as postulated by numerous authors, the sensitivity of ITT may be as low as 50 to $60 \%$. Consequently, culling of reactors does not always result in a complete elimination of the infection, although general epidemiological rules have been observed. The low reliability of ITT motivated the search for methods which would replace it, or, at least, give more precision to its results. One of the candidates is rapid agglutination (RA) with $M$. avium antigen (MAA).

Gallinaceous birds have been regarded as the major primary source of Mycobacterium avium for a long period. Numerous investigations, performed in Czechoslovakia and abroad, demons-- 
trated avian tuberculosis also in free-living bird species, such as sparrows, bulls, ducks, jackdaws, pheasants, rooks, kestrels, owls, and eagles (Hejlíček and Balát 1973). Avian tuberculosis is often diagnosed in exotic birds kept in zoological gardens.

Both in vivo and post mortem methods are used for the diagnosis of avian tuberculosis. X-ray and haematological examinations are the clinical methods usable on captive birds (Klimeš and Pavlas 1961).

More reliable results can be obtained by endoscopy, completed by bacterioscopic, histological and or bacteriological examination of bioptic samplex. Moreover, faeces and blood samples can be examined by culture. The probability of detection of mycobacteria is higher in birds than in mammals (Hartwig 1965; Roznyatovska 1975).

ITT, introduced in 1913, does not meet fully the requirements for sensitivity and specificity. Low reliability of ITT was reported by numerous authors (Fritzsche and Unruh 1958; Prochorov 1955). The failure to detect a $M$. avium infection aften results from anergy accompanying generalized tuberculosis. On the other hand, non-specific reactions to avian tuberculin are frequent in poultry and other animal species (Rozanska 1971). The first description of RA for the demonstration of tuberculosis in poultry was published by Moses at al. (1943) who examined blood serum samples. Karlson et al. (1950) developed the agglutination test for the examination of whole blood samples.

Numerous reports on the use of RA for the diagnosis of tuberculosis in poultry and other bird species were published in the second half of this century (Prochorov and Akulov 1958; Berger 1962; Švrěek 1962; Nassal 1963; Betke et al. 1964; Richter 1965; Hiller et al. 1967; Götz 1984; Neumann 1988). The test is based on the reaction of humoral antibodies with corpuscular antigens, represented by a suspension of mycobacteria. Under optimsi conditions, the agglutination takes place within several seconds. The simple test has become very popular and estimates of reliability of examinations of whole blood samples range from $80 \%$ for spontaneously infected to $95 \%$ for experimentally infected birds, respectively (Havlík 1960; Pavlas 1962).

High specificity and sensitivity of RA were also reported by Götz (1984), who found tuberculosis in only $2(0.6 \%)$ of 328 necropsied zoo birds reacting negatively in RA.

\section{Materials and Methods}

The strain 583 of $M$. avium serovar 2, 3 was selected for the production of the antigen from a set of field strains isolated from hen affected with the nodular form of tuberculosis. The selection was based on results of examinations of antigenic, biological, biochemical and growth characteristics.

The serum-containing liquid medium for mycobacteria, supplied by the Institute of Sera and Vaccines, Prague, proved to be the best of the available solid and liquid media for the propagation of $M$. avium. A well grown culture was centrifugated and washed twice with physiological saline with subsequent centrifugation. One part of the final sediment was resuspended in 25 parts of buffered physiological saline containing $0.5 \%$ of phenol. The suspension was left to stand at $22{ }^{\circ} \mathrm{C}$ for 7 days with daily shaking. The density was measured spectrophotometrically at $605 \mathrm{~mm}$ and adjusted to $15^{\circ} \mathrm{C}$ to $20^{\circ} \mathrm{C}$. The antigen was checked for specificity and sterility, and sensitivity activity checks were done using homologous and heterologous sera of rabbits immunized with strains of $M$. avium and $M$. intracellulare, respectively.

RA was carried out using serial twofold dilutions $(1: 2-1: 64)$ of the standard sera. Eight $\mu 1$ of the antigen and $2 \mu \mathrm{l}$ of the respective serum dilution were pipetted on to a glass plate and the two drops were combined carefully with a platinum loop. The plate was transluminated and the results were read after 20 to 60 seconds. The antigen was considered active if a marked agglutin:ate was formed with the positive serum dilution $1: 8$ within 60 seconds. No agglutination was observed with any of the heterologous sera or with physiological saline.

The sensitivity and specificity of the $M$. avium antigen were tested in poultry and pheasant flocks free of or infected with avian tuberculosis-mycobacteriosis as evidenced by complex examinations.

\section{Results}

As demonstrated in poultry flocks infected with tuberculosis, the diagnostic reliability of RA, but not that of ITT, increased at advanced stages of the infection (Fig. 1). 


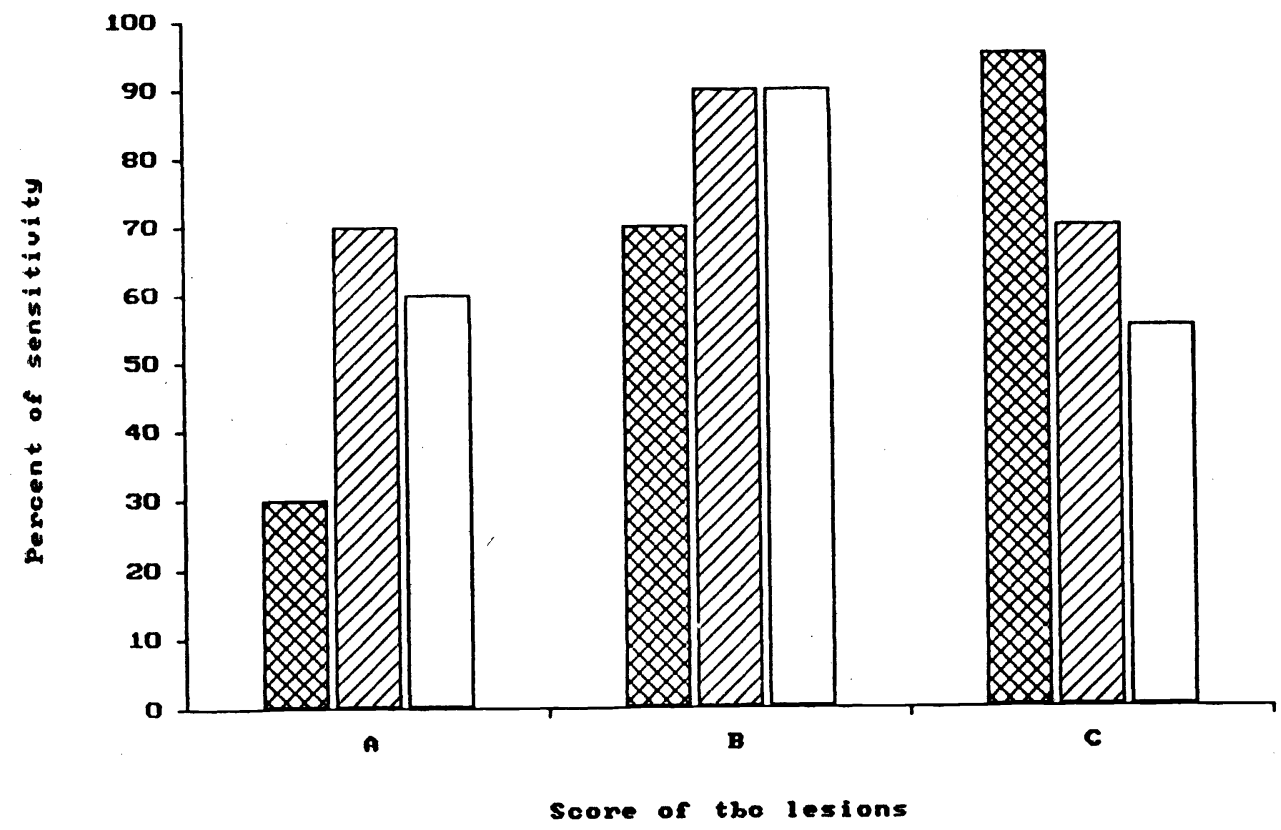

The reliability of both RA and ITT depended not only on the quality of the antigen or allergen, but also on the way and stage of infection and on the virulence of the inoculated mycobacteria. Higher sensitivities of both tests were observed in experimentally infected birds. ITT and whole blood RA were positive in the $6^{\text {th }}$ week after subcutaneous infection in $85 \%$ and $80 \%$ of the birds, respectively. On the other hand, 55,8\%, $41,9 \%$ and $95,2 \%$ of pullets infected orally with a virulent strain of $M$. avium serovar 2 reacted positively at the same stage of the infection in ITT, whole blood RA and blood serum RA, respectively. The highest specificity was recorded in birds reacting positively both in ITT and in RA. Results of ITT and RA and post mortem finding in 108 hens from a flock infected with avian tuberculosis are presented in Table 1.

False positive reactions to avian tuberculin occur not only in cattle and swine, but were observed also in avian tuberculosis-free poultry flocks. The paraallergic reactions were often induced by $M$. intracellulare, contaminating sawdust to be used for littering. Marked positive reactions to avian tuberculin were also observed in poultry infected experimentally with $M$. intracellulare. Positive reactions in ITT were recorded in $57,1 \%$ and $97,1 \%$ of pullets infected intramuscularly with this species. Simultaneous ITT with specific sensitins, prepared from the atypical mycobacteria $M$. intracellulare and $M$. avium failed to identify the type of allergy. Of the birds sensibilized with $M$. intracellulare, $74,6 \%$ and $68,6 \%$ reacted to specific sensitin and avian tuberculin, respectively. The corresponding values for the test repeated after 6 weeks were $88,2 \%$ and $82,3 \%$, respectively. On the other hand, whole blood RA, carried out parallelly with the repeated ITT, yielded $61,8 \%$ and $7,2 \%$ of positive results, respectively (Table 2 ).

The results have shown that the two antigens can be used for the differentiation of allergies induced by any of the two mycobacterial species. This conclusion was also confirmed by investigations in poultry farms from which paraallergic 
reactions to avian tuberculin were reported. Fifty percent of 3-month-old pullets reacted positively in ITT to avian tuberculin in a large farm and twenty reactors were examined by whole blood RA. While none of them reacted in the test with the $M$. avium antigen, 15 were positive when the $M$. intracellulare antigen was used (Table 3). M. intracellulare serovar 8 was isolated from sawdust to be used for littering in the farm. Blood serum RA demonstrated the presence of agglutinins more reliably than whole blood RA in birds infected experimentally with $M$. intracellulare. Positive reactions were obtained in $62,9 \%$ and $92,6 \%$ of the birds examined by whole blood RA and blood serum RA, respectively. The examination of blood sera reduced the number of non-specific reactions in RA with $M$. avium antigen to one half (Table 4).

RA failed to differentiate among birds infected experimentally with $M$. intracellulare serovars $4,3 a, 6-9$, or 5 .

\section{Discussion}

The reliability of RA in the diagnosis of avian tuberculosis-mycobacteriosis, postulated by other authors, has been confirmed and completed by the finding that RA can be used for the differentiation of allergic reactions to avian tuberculin induced by non-virulent serovars of the $M$. avium-intracellulare complex.

It has been demonstrated that the replacement of whole blood by blood serum increases the sensitivity and specificity of RA. The two parameters depend also on the selection of a suitable strain for the production of the mycobacterial antigen as well as of a culture medium supporting the formation of surface antigens, which are decisive for the activity and specificity of the product.

Table 1

Specificity of ITT and RA in adult chickens in flock infected with $M$. avium

\begin{tabular}{|c|c|c|c|c|c|c|c|}
\hline \multirow{3}{*}{$\begin{array}{l}\text { Number } \\
\text { of birds }\end{array}$} & \multirow{3}{*}{ Test } & \multirow{3}{*}{ Number } & \multirow{3}{*}{$\%$} & \multicolumn{4}{|c|}{ Post mortem findings } \\
\hline & & & & \multicolumn{2}{|c|}{ positive } & \multicolumn{2}{|c|}{ negative } \\
\hline & & & & number & $\%$ & number & $\%$ \\
\hline 108 & $\begin{array}{l}\text { ITT } \\
\text { whole blood RA } \\
\text { ITT + RA }\end{array}$ & $\begin{array}{l}32 \\
48 \\
28\end{array}$ & $\begin{array}{l}29.6 \\
44.4 \\
26.0\end{array}$ & $\begin{array}{l}24 \\
34 \\
28\end{array}$ & $\begin{array}{r}75.0 \\
70.8 \\
100.0\end{array}$ & $\begin{array}{r}8 \\
14 \\
0\end{array}$ & $\begin{array}{c}25.0 \\
29.2 \\
0\end{array}$ \\
\hline
\end{tabular}

Table 2

Reliability of RA in chickens infected experimentally with $M$. intracellulare

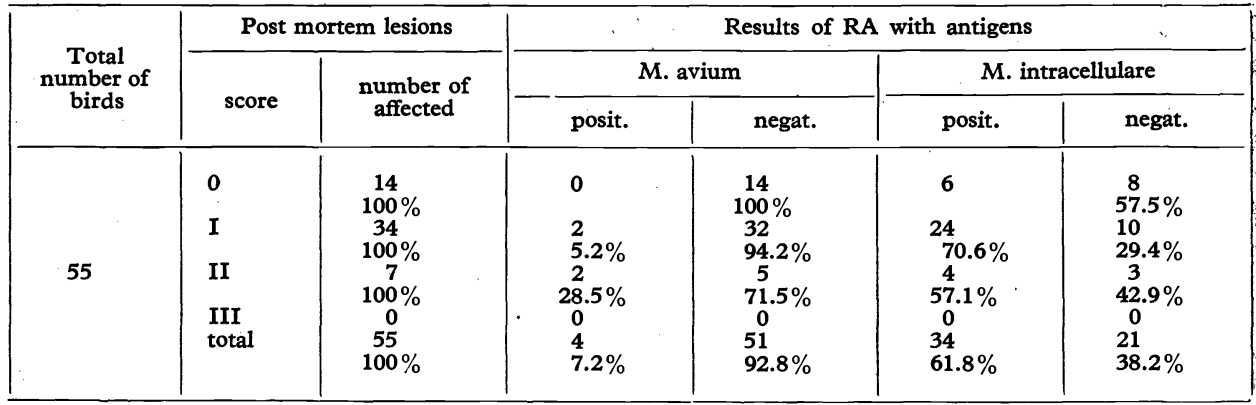


Table 3

Results of ITT and RA in flocks showing paraallergic reactions to avian tubereulin

\begin{tabular}{|c|c|c|c|c|c|c|}
\hline \multirow{2}{*}{ Total } & \multicolumn{2}{|c|}{$\begin{array}{c}\text { Number of birds } \\
\text { ITT }\end{array}$} & \multicolumn{2}{|c|}{ RA with antigens } \\
\cline { 2 - 7 } & positive & negat. & positive & negat. & positive & M. avium \\
\hline \multirow{2}{*}{21} & 20 & & 1 & 14 & 0 & 0 \\
0
\end{tabular}

Table 4

Reliability of whole blood and blood serum RA in chickens infected experimentally whit $M$. intracellulare

\begin{tabular}{|c|c|c|c|c|c|}
\hline \multirow{2}{*}{$\begin{array}{c}\text { Total number } \\
\text { of birds }\end{array}$} & Results & \multicolumn{2}{|c|}{ Blood serum RA antigen } & \multicolumn{2}{c|}{ Whole blood RA antigen } \\
\cline { 3 - 6 } & M. avium & M. intracellur. & M. avium & M. intracellur. \\
\hline \multirow{3}{*}{27} & positive & 1 & 25 & 2 & 17 \\
& \multirow{3}{*}{ negative } & $3.7 \%$ & $92.6 \%$ & $7.4 \%$ & $62.9 \%$ \\
& & 26 & 2 & 25 & 10 \\
& & $96.3 \%$ & $7.4 \%$ & $92.6 \%$ & $27.1 \%$ \\
\hline
\end{tabular}

ITT and RA provide reliable information especially for the control of avian tuberculosis by the elimination method. Parallel examinations by both the tests are recommended for this purpose. RA can replace ITT in the screening of tuberculosis in poultry flocks and other bird colonies. Its major merit is that each bird must be handled only once. RA is irreplaceable in water fowl and all other bird species in which ITT into wattle is not possible. Blood serum RA yields more accurate results and is recommended for the examination of birds kept in zoological gardens and rearing colonies of predatory birds.

\section{Diagnostika aviární tuberkulózy - mykobakteriózy pomocí RKA}

Při ověřováni citlivosti a specifity antigenu $M$. avium sérovaru $2,3 \mathrm{k}$ rychlé kapkové aglutinaci (RKA) jsme zjistili, že spolehlivost uvedené metody se zvyšovala $u$ vyšetřované drůbeže na rozdíl od tuberkulinace $s$ pokročilostí tuberkulózního procesu. U kuřic infikovaných per os virulentním kmenem $M$. avium sérovar $2, \mathrm{v}$ dávce $1 \mathrm{mg}$ kultury na $\mathrm{kg}$ ž. hm. reagovalo na aviární tuberkulin pouze $47,7 \%$. Při RKA reagovalo pozitivně v témže období při vyšetření plné krve $61,6 \%$ a krevního séra $90,9 \%$ drůbeže. V některých chovech drůbeže prostých aviární tuberkulózy byly zjištovány reakce na aviární tuberkulin, které nebyly vyvolány infekcí $M$. avium. Častou př́ícinou těchto reakcí byly piliny kontaminované $M$. intracellulare sérovar 8 . Antigen $M$. avium bylo možno použít pro odlišení paraalergických reakcí na aviární tuberkulin. Dosažené výsledky s tuberkulinací a RKA prokázaly, že antigen $M$. avium byl vhodný zejména pro vyšetření $\mathrm{v}$ chovech, ve kterých byla ozdravována drůbež nebo ptáci pomocí eliminační metody. V těchto případech doporučujeme použít současně tuberkulinace a RKA. Kromě toho bylo možno použít antigen $k$ RKA pro plošné vyšetření drůbeže a ptáků nahrazující tuberkulinaci. U ptáků $v$ zoologických zahradách nebo $\mathrm{v}$ chovech dravců doporučujeme $\mathrm{k}$ vyšetření použít krevního séra, kterým 
je možno zajistit přesnější výsledky. Výhodou antigenu $M$. avium $\mathrm{k}$ RKA je však jeho větší specifita ve srovnání $s$ tuberkulinací. Vzhledem $\mathrm{k}$ výskytu patogenních kmenů $M$. avium, které nelze zařadit do referenčních sérovarů $M$. avium $1,2,3$ doporučujeme věnovat výběru aviárních kmenů $k$ př́pravě antigenu i nadále pozornost.

\section{Диагностика түберкүлеза - микобактериоза птиц с помоцью RKA}

В ходе проверки чувствительности и специфичности антигена $M$. avium варки 2,3 для быстрого капельного агглютинирования [RKA] нами было установлено, что надежность данного метода увеличивалась у исследуемой птицы в противовес туберкулинизации с уровнем процесса туберкулеза. У күриц, перорально инфицированных вирулентным штаммом $M$. avium варки 2 дозой 1 мг культуры на 1 кг живой массы на авиарный туберкулин прореагировали лишь $47,7 \%$. При RKA позитивно в тот же период реагировали при исследовании крови $61,6 \%$ и кровяной сыворотки 90,9 \% птицы. В некоторых птицеводствах без наличия авиарного туберкулеза проводили исследования реакции на авиарный туберкулин, не вызванной инфекцией M. avium. Нередкой причиной данной реакции явились опилки, зараженные M. intracellulare варки 8. Антиген $M$. avtum можно было использовать для различия парааллергических реакций на авиарный туберкуин. Достигнутые результаты түберкулинизации и RKA выявили, что антиген $M$. avium пригоден в особенности для исследования на птицеводствах, в которых проводили оздоровление птицы или куриц методом элиминации. В данном случае рекомендуем одновременное применение туберкулинизации и RKA. Помимо этого можноприменик K RKA антиген для общего исследования птицы, заменяющий түберкулинизацию. У птиц в зоопарках или при разведении хищных птиц рекомендуем применение для исследования сыворотки, с помощью которой можно обеспечить более точные результаты. Выгодой антигена $M$. avium к RKA является его большая специфичность по сравнению с туберкулинизацией. Учитывая наличие патогенных штаммов $M$. avium, которые нельзя включить в исследуемые варки M. avium $1,2,3$, рекомендуем в дальнейшем уделять выбору авиарных штаммов Ап̣я подготовки антигена пристальное внимание.

\section{References}

BERGER, W.: Vergleichende Untersuchungen über die Leistungsfähigkeit der Frischblut-Schnellagglutination und der Tuberkulin-Kehllappenprobe bei der Diagnose der Hühnertuberkulose. Inaug. Dissertation der Tierärztlichen Fakultät der Ludwig-Maximilians-Universität, München, 1962: 67

BETKE, P.-BLUM, H.-GRAUBMANN, H. O.: Untersuchungen über die Frischblut-Schnellagglutination zur Diagnose der Hühnertuberkulose. Mh. Vet. Med., 19, 1964: 507-509

FRITZSCHE, K.-UNRUH, W.: Untersuchungen über eine Verbesserung der Technik der Tuberkulin-Kehllappenprobe beim Huhn. Berl. Münch. tierärztl. Wschr., 71, 1958: 303

GÖTZ, K.: Untersuchungen zur Erkennung und Kontrolle der aviären Tuberkulose in zoologischen Gärten mit Hilfe der Citratplasma-Schnellagglutination. Inaugural-Dissertation ser Tierärztlichen Fakultät der Ludwig-Maximilians-Universität, München, 1984: 100

HALf́k, J.: Diagnóza tbc u hydiny rychlou kvapkovou aglutináciou krví a sér. Vet. Cas., 9, 1960: $550-559$ 
HARTWIG, H.: Infektion bei Tieren durch aviäre Mykobakterien. Prax. Pneumol., 19, 1965: $537-543$

HILLER, K.-SCHLIESSER, T. H.-FONK, G.-DORN, P.: Zur serologischen Diagnose der Hühnertuberkulose, Berl. Münch. tierärztl. Wschr., 11, 1967: 212-216

KARLSON, A. G.-ZINOBER, M. R.-MANN, F. C.: A whole Blood rapid agglutination test for avian Tuberculosis. Am. J. vet. Res., 11, 1950: 137

KLIMES, B.-PAVLAS, M.: Príspěvek $k$ experimentální infekci slepic tuberkulózou. Acta universitatis agriculturae, Brno, ř. B: Spisy Fakulty veterinární, 1-2, 1961: 49-62

MOSES, H. E.-FELDMAN, H. W.-MANN, F. C.: Mycobacterial rapid agglutination antigens and their diagnostic Value in Tuberculosis Fowl. Am. J. vet. Res., 4, 1943: 390-394

NASSAL, J.: Untersuchungen über Brauchbarkeit der Frischblut-Schnellagglutination zur Feststellung der Tuberkulose beim Huhn. Mh. Tierheilk. 15, 1946: 109-116

NEUMANN, H.: Serodiagnostik und Erregeridentifizierung bei aviären Mykobakteriosen. Inaug. Dissertation aus dem Institut für Geflügelkrankheiten der Ludwig-Maximilians-Universität, München, 1988: 66

PAVLAS, M.: Spolehlivost kapkové aglutinace při diagnostice tuberkulózy u drůbeže. Vet. Med., Praha, 7, 1962: 43-52

PROCHOROV, A. V.: Praktičeskije meroprijatija dlja likvidacii tuberkuloza ptic. Veterinarija, 32, 1955: 40-41

PROCHOROV, A. V.-AKULOV, A. V.: Diagnostičeskaja cennost krove-kapelnoj reakcii agglutinacii pri tuberkuloze kur. Veterinarija, 35, 1958: 45-48

RICHTER, W.: Die Entwicklung eines Antigens für die Frischblut-Schnellagglutination zur Diagnose der Geflügeltuberkulose. Arch. exp. Vet. Med., 19, 1, 1965: 297-299

ROZANSKA, M.: Wplyw pratków atypowych na powstawanie dodatnich odczynów tuberkulinowych u kur. Medycyna wet., 27, 1971: 221-224

ROZNJATOVSKA, O. I.: Do pytannja epizootologii ta diagnostiky tuberkulozu ptyci. Veterinarija, Kiev, 1974: $81-83$

STOLL, L. - LUCAS, H.: Vergleichende Untersuchungen zur Diagnose der Geflügeltuberkulose mit Hilfe der Tuberkulin-Kehllappenprobe und der Frischblut-Schnellagglutination. Thierheilk., 15, 1963: 163-169

ŠRČEK, S.: Sérologická diagnostika tbc slepic. Folia vet., Košice, 6, 1962: 115-153 